\title{
Cerebrospinal metastases in malignant childhood astrocytomas
}

\author{
Raymond S Kandt,* Shlomo Shinnar, Bernard J D'Souza, Harvey S Singer, Moody D Wharam \& Prabodh \\ K Gupta \\ Departments of Neurology, Pediatrics, Radiology, Oncology and Pathology, Johns Hopkins University, \\ School of Medicine, 600 North Wolfe Street, Baltimore, MD 21205, USA
}

Keywords: malignant astrocytomas, metastases, cerebrospinal

\begin{abstract}
Over a period of five years, antemortem diagnosis of leptomeningeal spread was made in six of thirteen children with high grade astrocytomas. These included four of seven children with hemispheral tumors and two of six children with malignant brainstem gliomas. Leptomeningeal spread was diagnosed by the clinical picture and CSF profile. Meningeal spread occurred an average of 5 months (range 0-16) after initial diagnosis of tumor was made. Several patients responded well to local radiation and/or chemotherapy. Mean survival after evidence of meningeal spread was 7 months (range 2-16) with one patient still alive.

Meningeal spread of malignant childhood astrocytomas appears to be common and should be sought for in these patients as local radiation is beneficial. Serious consideration should be given to a controlled trial of prophylactic craniospinal radiation in thee tumors. The role of chemotherapy also requires further study.
\end{abstract}

\section{Introduction}

Glioblastoma multiforme is a malignant brain tumor of glial origin with rapid growth and a fatal course. The tumor comprises approximately $15-20 \%$ of intracranial tumors in adults $3-11 \%$ in children (1). Its course is characterized by rapid local extension, sometimes with meningeal involvement, but it only occasionally metastasizes via cerebrospinal-fluid (CSF) pathways. This report describes our experience with six children with malignant astrocytomas (grades III and IV) in whom spinal meningeal dissemination was diagnosed. Our data suggest that CSF metastases may be a common complication of high grade astrocytomas, and that the use of spinal irradiation or chemotherapeutic agents is of short-term benefit.

\footnotetext{
* Current Address: Pediatric Neurology, University of Michigan Medical Center, Ann Arbor, MI 48109-0010, USA.
}

\section{Materials and methods}

During the five year period, June 1977 to June 1982, 90 new cases of primary brain or optic nerve tumors were diagnosed in children under the age of 17 years at the Johns Hopkins Hospital pediatric neurology service. Of this group, 19 had supratentorial astrocytomas of which seven were grade III or IV based on the pathologic criteria defined by Kernohan and Sayre (2). All 19 were biopsied. Ten had brainstem gliomas of which 4 had a clinical picture and course consistent with a low grade glioma ( 1 confirmed by biopsy) and 6 appeared to have a grade III-IV glioma of which 3 were confirmed by biopsy or CSF cytopathology (3).

At many institutions, it is now common to restrict the term glioblastoma multiforme to either grade IV astrocytomas or poorly differentiated anaplastic tumors of glial origin for which there is no definite evidence of a preexisting astrocytoma. 
Grade III astrocytomas are often referred to as malignant or anaplastic astrocytomas. Since it is difficult to clearly distinguish between grades three and four astrocytomas on the basis of a biopsy specimen (4), these cases have been combined and represent the study population. Autopsy permission was denied.

\section{Results}

Among the thirteen children with high-grade tumors, six had clinical evidence of meningeal spread (Tables 1 and 2, Cases 1-6). There were no known instances of meningeal spread in the twelve children with grade I and II supratentorial astrocytomas or the four children with low-grade brainstem gliomas.

Of the six cases with evidence of meningeal spread, four had primary hemispheral tumors and two had pontine gliomas. The mean age of onset was 9.1 years for the hemispheral tumors (range: 5 months- 15 years) and 6.9 years for the brainstem gliomas (range: $49 / 12-9$ years). Diagnoses were based on neuroradiographic studies in all cases and, in 5 of the cases, on tumor biopsy as well. Diagnosis in case 5 (not biopsied) was based on the clinical picture, CT scan and malignant tumor cells in CSF
(Fig. 1A). Meningeal spread of the primary tumor in Cases 1-6 was diagnosed by clinical symptomatology, neurological exam, CSF cytology (Fig. 1B) and response to therapy. All but Case 5 had alterations in tone and most had diminution of reflexes. In the five cases (2-6) where a lumbar puncture or shunt tap was performed, all had abnormal CSF findings (Table 3): cytopathology positive in $3 / 5$, increased protein $3 / 5$, leukocytes $3 / 5$. In patients 2 and 3, cranial computerized tomography showed abnormal tentorial or periventricular enhancement, suggestive of CSF spread (Fig. 2).

The mean interval between diagnosis of the primary tumor and evidence of meningeal involvement was five months (range $0-16$ months). Following the diagnosis of spinal metastasis, all patients except Case 4 received either local cord irradiation, intrathecal methotrexate/thiotepa or systemic cisplatinum. Symptomatic response was noted in every case, ranging from diminution of pain to improved mobility. In the five deceased patients in whom antemortem diagnosis of meningeal spread was made, mean survival was 13 months from the diagnosis of the primary tumor (range: 3-22 months) and 7 months from onset of myelopathy or radiculopathy (range: 2-16 months). One patient (Case 5) is still alive 14 months from the diagnosis of her tumor and of CSF spread.

Table 1. Clinical summary of patients.

\begin{tabular}{|c|c|c|c|c|c|c|}
\hline Case & $\begin{array}{l}\text { Age at time of } \\
\text { diagnosis } \\
\text { (years) }\end{array}$ & Presenting symptoms & $\begin{array}{l}\text { Location of } \\
\text { tumors }\end{array}$ & Pathology & Initial treatment & $\begin{array}{l}\text { Survival after } \\
\text { diagnosis } \\
\text { (months) }\end{array}$ \\
\hline 1 & 10 & Gait disorder & $\mathrm{R}$ parietal & Grade IV & $\begin{array}{l}4500 \text { rads whole brain } \\
\text { together with metronidazole } \\
5400 \text { rads to tumor }\end{array}$ & 22 \\
\hline 2 & 15 & Headache \& seizure & $\begin{array}{l}\text { L temporo- } \\
\text { parietal }\end{array}$ & $\begin{array}{l}\text { Grade IV } \\
\text { (gemistocytic) }\end{array}$ & 3000 rads whole brain & 3 \\
\hline 3 & 11 & Seizures \& lethargy & $\begin{array}{l}\text { L temporo- } \\
\text { parietal }\end{array}$ & Grade III & $\begin{array}{l}4500 \text { rads whole brain } \\
5940 \text { rads to tumor }\end{array}$ & 15 \\
\hline 4 & $5 / 12$ & $\begin{array}{l}\text { Lethargy \& decreased } \\
\text { feeding }\end{array}$ & $\begin{array}{l}\text { L temporo- } \\
\text { parietal }\end{array}$ & Grade IV & 3960 rads to tumor & 16 \\
\hline 5 & 9 & $\begin{array}{l}\text { Headaches \& cranial } \\
\text { nerve palsies }\end{array}$ & Brainstem & $\begin{array}{l}\text { Malignant } \\
\text { astrocytes on } \\
\text { cytopathology } \\
\text { of } \mathrm{CSF}\end{array}$ & $\begin{array}{l}4500 \text { rads whole brain } \\
5400 \text { rads posterior fossa }\end{array}$ & $\begin{array}{l}\text { Alive at } \\
\text { I } 4 \text { mo }\end{array}$ \\
\hline 6 & $49 / 12$ & $\begin{array}{l}\text { Right cerebellopontine } \\
\text { angle hemorrhage }\end{array}$ & Brainstem & grade III & 5040 rads posterior fossa & 7 \\
\hline
\end{tabular}


Table 2. Clinical course of meningeal spread of patients with antemortem diagnosis.

\begin{tabular}{|c|c|c|c|c|c|c|}
\hline Case & $\begin{array}{l}\text { Time from } \\
\text { diagnosis } \\
\text { tumor to } \\
\text { meningeal } \\
\text { spread } \\
\text { (months) }\end{array}$ & Clinical symptoms & $\begin{array}{l}\text { Status of primary } \\
\text { tumor at time of } \\
\text { meningeal spread }\end{array}$ & Treatment & $\begin{array}{l}\text { Initial } \\
\text { response } \\
\text { to } \\
\text { therapy }\end{array}$ & $\begin{array}{l}\text { Survival } \\
\text { after } \\
\text { meningeal } \\
\text { spread } \\
\text { (months) }\end{array}$ \\
\hline 1 & 16 & $\begin{array}{l}\text { Radiating lumbosacral pain, } \\
\text { decreased sensation over } \\
\text { T10-T12 distribution and } \\
\text { diminished left knee jerk }\end{array}$ & $\begin{array}{l}\text { Recurrence two } \\
\text { months prior to } \\
\text { meningeal spread }\end{array}$ & $\begin{array}{l}1200 \text { rads to } \\
\text { thoracolumbar spine }\end{array}$ & Complete & 6 \\
\hline 2 & 1 & $\begin{array}{l}\text { Nuchal rigidity, bilateral } \\
\text { arm weakness, back pain } \\
\text { and constipation }\end{array}$ & $\begin{array}{l}\text { Enlarging, } \\
\text { unresponsive to } \\
\text { therapy }\end{array}$ & $\begin{array}{l}2000 \text { rads to } \\
\text { cervical spine }\end{array}$ & Partial & 2 \\
\hline 3 & 8 & Low back pain & $\begin{array}{l}\text { Smaller by CT } \\
\text { scans, no } \\
\text { clinical } \\
\text { symptoms } \\
\text { referrable to } \\
\text { brain }\end{array}$ & Cis-platinum & Complete & 7 \\
\hline 4 & 0 & $\begin{array}{l}\text { Areflexia in lower } \\
\text { extremities }\end{array}$ & $\begin{array}{l}\text { Primary tumor } \\
\text { and meningeal } \\
\text { spread diagnosed } \\
\text { concurrently }\end{array}$ & None & & 16 \\
\hline 5 & 0 & $\begin{array}{l}\text { (Positive cytopathology } \\
\text { on shunt tap) }\end{array}$ & $\begin{array}{l}\text { Primary tumor } \\
\text { (swollen pons by } \\
\text { CT scans) and } \\
\text { meningeal spread } \\
\text { diagnosed } \\
\text { concurrently }\end{array}$ & $\begin{array}{l}\text { Received } 3500 \text { rads } \\
\text { spinal radiation } \\
\text { prophylactically }\end{array}$ & - & $\begin{array}{l}\text { Alive at } \\
14 \text { months }\end{array}$ \\
\hline 6 & 5 & $\begin{array}{l}\text { Abrupt onset of flaccid } \\
\text { paraparesis, urinary } \\
\text { retention, and lax anal } \\
\text { sphincter tone. Normal } \\
\text { arm function. }\end{array}$ & $\begin{array}{l}\text { Progressively } \\
\text { enlarging }\end{array}$ & $\begin{array}{l}\text { Steroids and } 2100 \\
\text { rads to lumbosacral } \\
\text { spine }\end{array}$ & Partial & 2 \\
\hline
\end{tabular}

\section{Discussion}

Subarachnoid dissemination of malignant astrocytoma/glioblastoma multiforme, outside the area of the primary tumor or operative site, was pre- viously considered quite rare $(5,6)$. Recently, however, two large autopsy series of 77 patients with high grade astrocytomas, reported an approximately $25 \%$ incidence of leptomeningeal metastases in patients ranging from 5 to 69 years, two of whom

Table 3. CSF profile in patients with antemortem diagnosis of meningeal dissemination.

\begin{tabular}{|c|c|c|c|c|c|c|}
\hline Case & $\begin{array}{l}\text { Source } \\
(\mathrm{mg} / \mathrm{dl})\end{array}$ & $\begin{array}{l}\text { Glucose } \\
\text { (mg/dl) }\end{array}$ & Protein & WBC & $\mathrm{RBC}$ & Cytopathology \\
\hline 1 & - & - & - & - & - & - \\
\hline 2 & LP & 8 & 234 & 102 & 7600 & Positive \\
\hline 3 & LP & 42 & 2610 & 88 & 2500 & $\begin{array}{l}\text { Necrotic } \\
\text { debris }\end{array}$ \\
\hline 4 & LP & 38 & 37 & I & 0 & Positive \\
\hline 5 & Shunt tap & 72 & 5 & 0 & 0 & Positive \\
\hline 6 & $\mathrm{LP}$ & 92 & 77 & 26 & 628 & Negative $\times 2$ \\
\hline
\end{tabular}




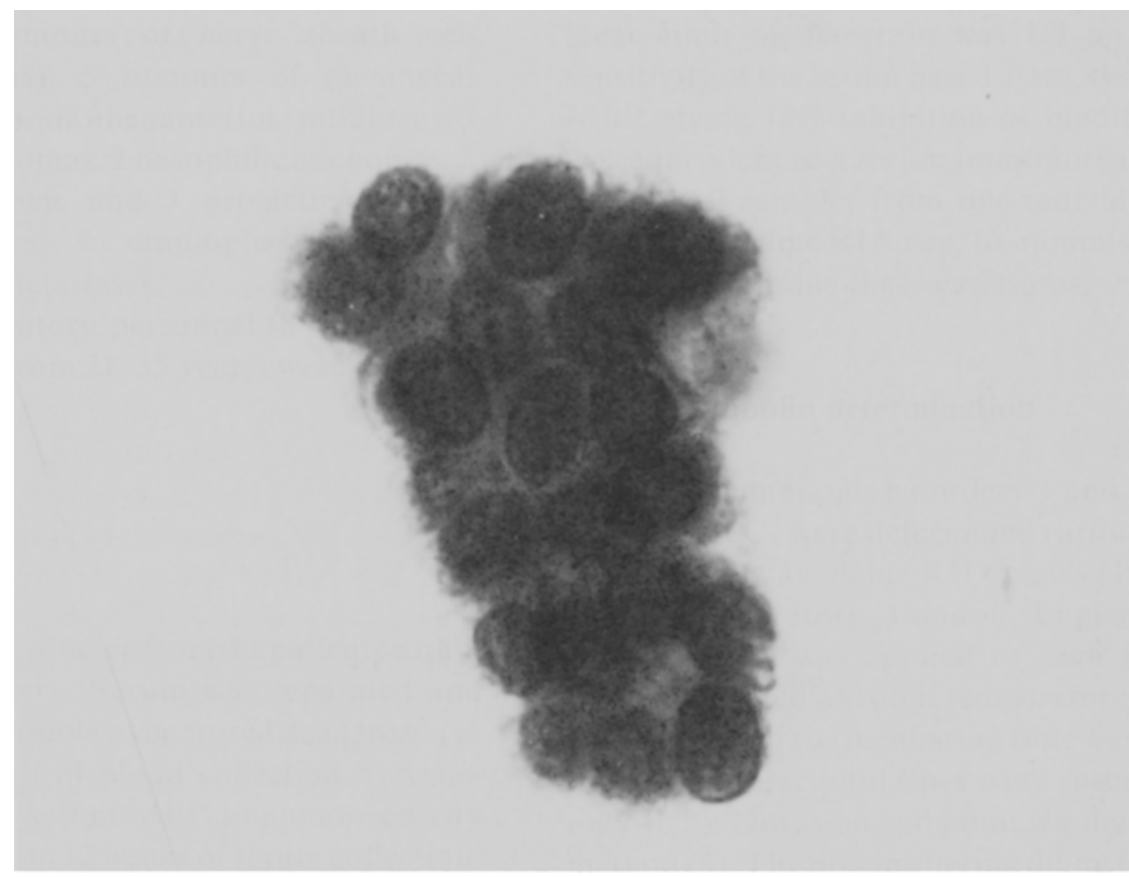

(A)

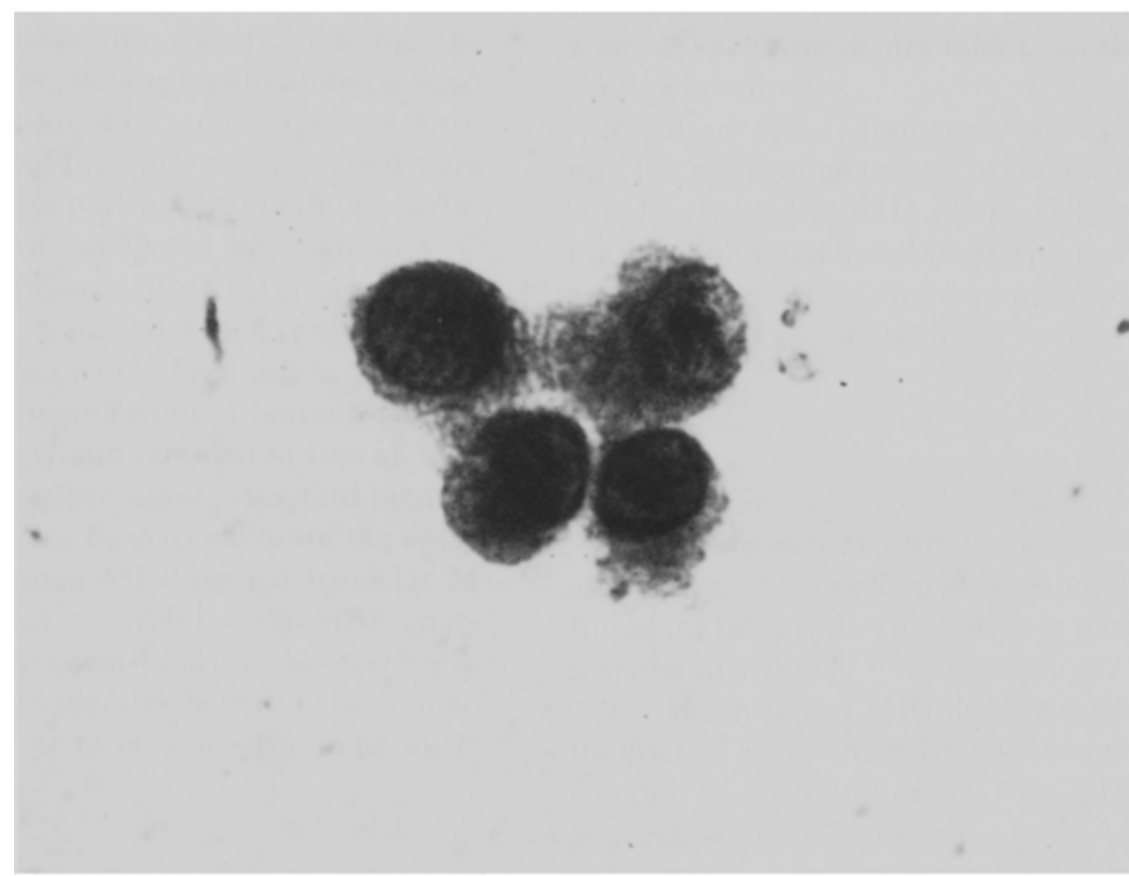

(B)

Fig. I CSF Cytopathology in malignant astrocytomas. (A) Tissue fragment of tumor cells in the CSF in malignant brainstem glioma Note the pleomorphism. Millipore filter $\times 787$. (B) Group of tumor cells in CSF of patient with hemispheric malignant astrocytoma. Note the nuclear membrane thickness irregularity and prominent nucleoli. Millipore filter $\times 787$. 


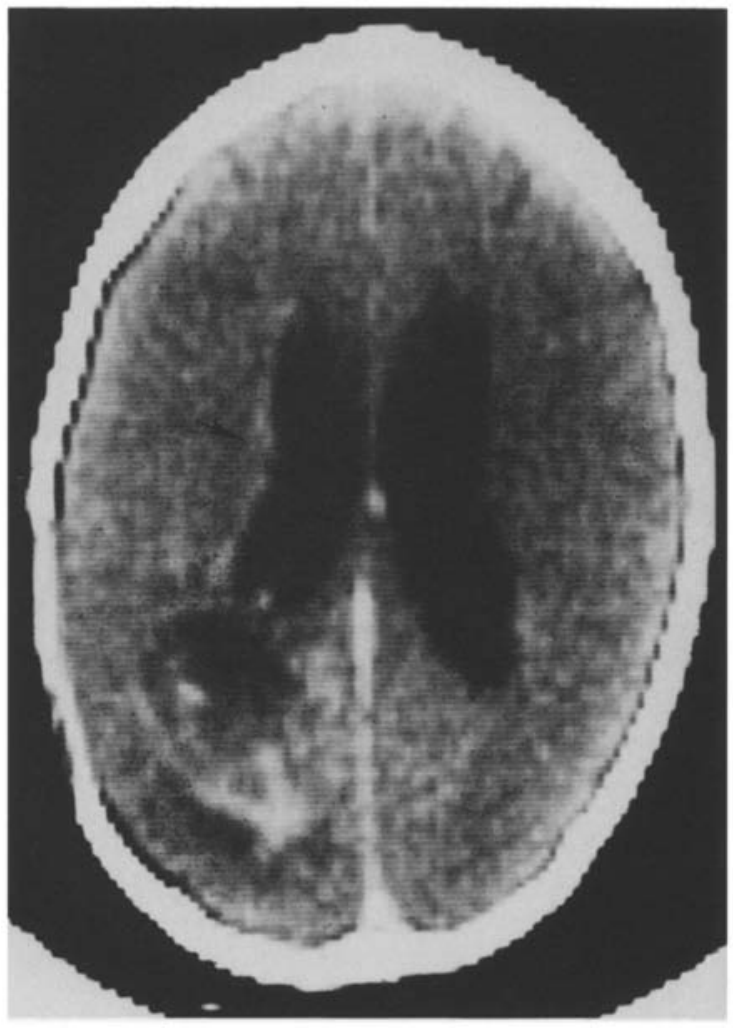

Fig. 2. CT evidence of CSF spread. Enhanced CT scan of the patient with left temporoparietal grade III glioma and clinical evidence of cerebrospinal dissemination. Note periventricular enhancement on left side suggesting CSF spread (arrow).

were children $(7,8)$. In one of these series (8) eight of twelve cases were diagnosed antemortem. A small group of five patients with atypical juvenile astrocytomas and subarachnoid spread has also been reported (9). Spinal leptomeningeal metastases originating from a pineal glioblastoma multiforme have also been reported (10). The frequency of subarachnoid spread of malignant brainstem gliomas remains controversial. One recent pediatric autopsy series reported anatomical evidence of spread in seven of sixteen cases (11) while another series with pediatric and adult cases found only one instance of subarachnoid spread in 25 cases (12). Finally, in a series with fifteen cases presenting as brainstem gliomas (13), five (33\%) developed leptomeningeal metastases.

This study differs from previous reports in that it is restricted to the pediatric population, specifically children less than age 17 . In our 5 year period of analysis none of the twelve patients with grade one or two supratentorial astrocytomas nor the four patients with low-grade brainstam gliomas showed clinical evidence of subarachnoid spread. However, six out of thirteen cases of malignant astrocytomas (grades three or four) developed signs or symptoms of spinal meningeal seeding.

For the last three years of the study, evidence of meningeal spread was systematically looked for in all patients with high grade gliomas. In our patients, there was no specific clinical pattern characteristic of leptomeningeal invasion. Findings included: stiff neck, back pain, sensory loss, hypotonia, weakness, depressed or absent reflexes and decreased anal tone or bowel and bladder incontinence. These are similar to those described in adults with meningeal spread and to adults with carcinomatous meningitis (8). Although it was sometimes difficult to determine whether these clinical findings represented meningeal spread or direct tumor extension, particularly in the case of brain stem gliomas, supportive evidence included the presence of nuchal rigidity, the CSF profile, or CT scans. As meningeal irritation may also be the result of cerebellar herniation, subarachnoid, hemorrhage, infectious meningitis or spillage of necrotic tumor material producing a chemical meningitis (14), the analysis of CSF and cranial CT scans was helpful, especially when other findings consistent with a gliomatous meningitis were present. Cranial CT scans demonstrated periventricular enhancement in two patients, findings supportive of a disseminated meningeal tumor. The utility of cranial CT scans in providing reliable evidence for meningeal invasion has been described (15). Finally, the beneficial response of spinal cord signs and symptoms to local irradiation or chemotherapy has further supported the diagnosis of spinal subarachnoid spread.

The current prognosis of patients with glioblastoma multiforme is poor (16). It has been suggested that the documentation of spinal spread is not worthwhile since the primary tumor is fatal before symptoms of spinal seeding are present (17). In our cohort, spinal cord symptoms were the source of great discomfort and occurred months prior to death in all our cases. Significant, albeit temporary, improvements in the well-being of the patients were achieved with therapy. As newer primary che- 
motherapeutic agents providing further increases in survival time are discovered, recognition of subarachnoid spread will become increasingly important.

Some authorities now recommend prophylactic craniospinal irradiation for all childhood malignant cerebellar astrocytomas (18) or at least for selected infratentorial malignant astrocytomas (19). In one recent series of thirteen children with cerebellar malignant astrocytomas, five of six who received only cranial irradiation developed subarachnoid metastases while none of the seven who received craniospinal irradiation demonstrated subarachnoid spread (18). However, all of those who developed subarachnoid spread had received less than 5000 rads to the primary tumor while those who did not had received 5550-5 580 rads to the primary site raising the issue of whether the initial dose of radiation is the determining factor (20). Care must also be taken in differentiating subarachnoid spread defined by clinical symptomatology versus asymptomatic positive cytopathology (21).

We report a $46 \%$ incidence of subarachnoid spread in malignant childhood astrocytomas with a good temporary response to palliative therapy in the majority of patients. It is not clear when the spread occurs. If it occurs at the time of biopsy or initial tumor occurrence, as has been reported in germinomas, then prophylactic spinal irradiation is warranted. On the other hand, if subarachnoid spread occurs at the time of tumor recurrence or later, then prophylactic spinal radiation would be ineffective and contraindicated. A controlled trial of prophylactic spinal radiation versus radiation at the time of tumor spread merits consideration. Chemotherapy of brain tumors in general is still in its infancy. A continuous search for more effective chemotherapy is essential.

\section{References}

1. Dohrmann GJ, Farwell JR, Flannery JT: Glioblastoma multiforme in children. J. Neurosurg 44:442-448, 1976.
2. Kernohan JW, Sayre GP: Tumors of nervous tissue. In: Atlas of Tumor Pathology, Section 10, Fascicles 35 and 37. Armed Forces Institute of Pathology, Washington, DC, 1952, pp 17-42.

3. Watson CW, Hajdu SI: Cytology of primary neoplasms of the central nervous system. Acta Cytologica 21:40-47, 1977.

4. Graham DI: Primary malignant tumors of the cerebral hemis pheres of adults. In: Thomas DGT, Graham DI (eds) Brain Tumors. Scientific basis, clinical investigation and current therapy. Butterworths, London, 1980, p 280.

5. Cairns H, Russell DS: Intracranial and spinal metastases in gliomas of the brain. Brain 54:377-420, 1931.

6. Eade $\mathrm{OE}$, Urich $\mathrm{H}$ : Metastasising gliomas in young subjects. J Path 103:245-256, 1971.

7. Erlich SS, Davis RL: Spinal subarachnoid metastasis from primary intracranial glioblastoma multiforme. Cancer 42:2854-2864, 1978

8. Yung WA, Horten BC, Shapiro WR: Meningeal gliomatosis: A review of 12 cases. Ann Neurol 8:605-608, 1980.

9. McLaughlin JE: Juvenile astrocytomas with subarachnoid spread. J Path 118:101-107, 1976.

10. Norbut AM, Mendelow H: Primary glioblastoma multiforme of the pineal region with leptomeningeal metastases: A case report. Cancer 47:592-596, 1981.

11. Littman P, Jarrett P, Bilaniuk LT, Rorke LB, Zimmerman RA, Bruce DA, CarabelI Sc, Schut L: Pediatric brain stem gliomas. Cancer 45:2787-2792, 1980.

12. Mantravadi RVP, Phatak R, Bellur S, Liebner EJ, Haas R: Brain stem gliomas: an autopsy study of 25 cases. Cancer 49:1294-1296, 1982

13. Packer RJ, Allen J, Nielsen S, Petito C, Deck M, Jereb B: Brain stem glioma: clinical manifestations of meningeal gliomatosis. Ann Neurol 14:177-182, 1983.

14. Bernat JL: Glioblastoma multiforme and the meningeal syndrome. Neurology (Minneap) 26:1071-1074, 1976.

15. Ascherl GF, Hilal SK, Brisman R: Computed tomography of disseminated meningeal and ependymal malignant neoplasms. Neurology (NY) 31:567-574, 1981.

16. Salcman M: Survival in glioblastoma: historical perspective. Neurosurgery 7: 435-439, 1980.

17. Bryan P: CSF seeding of intra-cranial tumors: A study of 96 cases. Clin Radiol 25: 355-360, 1974.

18. Salazar OM: Primary malignant cerebellar astrocytomas in children: a signal for postoperative craniospinal irradiation. In J Radiation Oncology Biol Phys 7:1661-1665, 1981 .

19. Kopelson G, Linggood R: Infratentorial glioblastoma: the role of neuraxis irradiation. Int $\mathrm{J}$ Radiation Oncology Biol Phys 8:999-1003, 1982.

20. Kopelson G: Cerebellar glioblastoma. Cancer 50:308-311, 1982.

21. Glass JP, Melamed M, Chernik NL, Posner JB: Malignant cells in cerebrospinal fluid (CSF): The meaning of a positive CSF cytology. Neurology (Minneap) 29:584, 1979. 